\title{
AS ORIGENS DO PROCESSO DE INSTITUCIONALIZAÇÃO DA PROFISSÃO DOCENTE NA PROVÍNCIA DE SERGIPE: um estudo sobre a Lei Geral de 15 de outubro de 1827 e a Lei Provincial de 5 de março de 1835.
}

\author{
Simone Silveira Amorim ${ }^{1}$ \\ Cristiano de Jesus Ferronato ${ }^{2}$ \\ Leyla Menezes de Santana ${ }^{3}$
}

\section{RESUMO}

Este artigo tem como objetivo compreender como se deu o início do processo da configuração da profissão docente através da análise da legislação, especialmente da lei de 15 de outubro de 1827 e da lei provincial de 5 de março de 1835, em Sergipe. Para o estudo da configuração da profissão docente em Sergipe consideramos nesta análise a necessidade de ter a lei como fonte. Dessa forma, as categorias analíticas de Bourdieu (1998) e Elias $(1990,2001)$ ajudaram a compreender como se configurou a profissão docente no âmbito do ensino primário e de que forma se constituiu o habitus profissional pensado para o projeto de constituição de Nação para o Brasil, dentro de um processo civilizador. É possível afirmar que a profissão docente se configurou em meio a avanços e retrocessos, permeados por tentativas de organização do ensino primário através da legislação. As questões em torno da formação dos professores no Brasil e especificamente na Província de Sergipe contribuíram para a edificação de discursos a respeito da instrução e da configuração da profissão docente, pois elas fomentaram diversas ações do Estado. Palavras-chave: Profissão Docente; Sergipe; Ensino Primário.

\section{THE ORIGINS OF THE TEACHING PROFESSION INSTITUTIONALIZATION PROCESS IN THE PROVINCE OF SERGIPE: a study on the General Law of October 15, 1827 and the Provincial Law of March 5, 1835.}

\begin{abstract}
This article aims at understanding how the primary school configuration of the teaching profession process started and the happened through the analysis of legislation, specially the Law of October 15, 1827 and the provincial law of March 5, 1835, in Sergipe. In order to study the configuration of the teaching profession in Sergipe it is necessary to have the law as a source. Therefore, the analytical categories of Bourdieu (1998) and Elias (1990, 2001), helped understand how the teaching profession in the primary school was set up and how the professional habitus was built up having in mind the ideal of constituting Brazil as a nation, in a civilizing process. It is possible to say the teaching profession was set between advances and drawbacks, permeated by attempts to organize the primary teaching through legislation. The issues surrounding the training of teachers in Brazil and specifically in the province of Sergipe contributed to the building of speeches about education and the configuration of the teaching profession, as they promoted various state actions.
\end{abstract}

Keywords: teaching profession. Sergipe. primary school. 


\section{Introdução}

O processo de construção da Nação Brasileira teve inicio com a transmigração da Corte Portuguesa (1808) para sua colônia, impulsionada pelos avanços franceses em direção à Península Ibérica. Napoleão Bonaparte (1769-1821), que assumiu o trono francês em 1804, desejou por em prática seus objetivos expansionistas ainda que consciente da força de seu oponente: a Inglaterra que, além de uma frota naval, também era política e economicamente privilegiada. Dessa forma, o imperador francês decretou o Bloqueio Continental, em 1807, a fim de impedir o comércio inglês. Como Portugal mantinha relações comerciais com a Inglaterra, também temia a ameaça militar francesa. Assim, para evitar o confronto armado com as duas potências, D. João optou pela neutralidade no conflito.

Com o acirramento do conflito, o Monarca avaliou que política e economicamente era muito mais interessante para Portugal continuar mantendo boas relações com os ingleses, uma vez que se ficasse a favor dos franceses, a Inglaterra poderia, em represália, ocupar o Brasil - sempre muito cobiçado pelas nações europeias, principalmente por conta das riquezas naturais, posicionamento estratégico, extensão territorial e pelas trocas comerciais promissoras.

O príncipe regente recebeu a notícia da invasão do território português por tropas francesas apenas no dia 23 de novembro e, logo em seguida, convocou o Conselho de Estado, que decidiu que toda a Família Real e o Governo deveriam embarcar o quanto antes, servindo-se da esquadra que estava pronta para o Príncipe da Beira e as infantas. Nos três dias seguintes outros navios foram preparados para transportar para o Brasil cerca de quinze mil pessoas. No dia 26 do mesmo mês, foi nomeada uma Junta Governativa do Reino para permanecer em Portugal e dadas instruções aos Governadores, nas quais se dizia que, quanto possível fosse, deviam procurar conservar em paz o Reino, recebendo bem as tropas do Imperador. (COSTA E SILVA, 2011).

A partir daquele momento capital, na construção da identidade nacional verificouse uma participação cada vez maior do Estado na construção de um aparato instrucional incluído a instrução elementar.

Dessa forma, temos que, a escolarização tornou-se um dos elementos principais para a afirmação do Estado Imperial. Esse interesse pode ser notado quando a legislação relativa ao assunto já demonstrava a preocupação de que houvesse um "[...] aumento e prosperidade da instrução pública”. (MOACYR, 1936, p. 61).

Com uma população dividida entre funcionários públicos, estrangeiros, advogados, engenheiros, padres, dentre outros, era preciso agir em favor do desenvolvimento da instrução pública. Especialmente porque instruir as crianças era condição essencial e para tal era necessário ter professores em número suficiente para executar a tarefa.

A situação descrita era o prenúncio da necessidade de uma ação direta do Estado que culminou com a publicação da Lei de 15 de outubro de 1827, que autorizou a criação de escolas de Primeiras Letras em todas as vilas, cidades e lugares mais populosos onde esse tipo de ensino fosse necessário. Ou seja, era preciso montar uma estrutura em que houvesse professores suficientes para ensinar não somente na Corte, mas em todo o Brasil.

A Lei de 1827 representou um passo importante no que diz respeito ao processo civilizador brasileiro. (ELIAS, 1990). Assim, era preciso não apenas organizar a Instrução Pública sob a égide do Estado, mas criar um habitus (1998), de alunos do ensino primário entre os brasileiros, que implicaria não apenas no ato de ir à escola e "gastar" tempo nela, 
mas toda uma concepção do que seria isso efetivamente, incluindo a família nesse processo.

D. João VI tinha a intenção de fazer do Brasil o império americano de Portugal, para tal, mandou abrir estradas, organizar a estrutura administrativa do governo, construir fábricas e escolas. $\mathrm{O}$ ensino religioso, com provas ministradas dentro das igrejas, foi substituído pelo leigo. No entanto, grande seria essa empreitada e uma série de medidas foram tomadas. Uma delas foi passar a responsabilidade de organização do ensino para as províncias, com a promulgação do Ato Adicional de 1834, publicado 3 anos após a abdicação de D. Pedro I.

O Ato Adicional foi o marco que desencadeou uma vasta discussão entre centralização e descentralização no Brasil imperial, não só para os contemporâneos, mas também entre os estudiosos do período, principalmente do campo educacional. Quem teria o poder de legislar sobre educação? A quem caberia a tarefa de organizar a instrução pública? Ao governo geral ou as províncias?

No sentido de assumir de forma efetiva o controle da instrução o Estado deu início ao processo de organização do ensino primário com a criação de cadeiras e de toda uma legislação específica que foi utilizada para legitimar o processo sendo desta forma o ente norteador das atividades da Nação brasileira. Desta forma, a escolarização tornou-se um dos elementos principais para a afirmação do Estado Imperial e, tendo ele tomado a responsabilidade para si, foi preciso lançar mão da legislação para que se fizesse valer a autoridade de poder público para institucionalizar a escola e configurar a profissão docente.

Temos então que compreender como as práticas civilizatórias da educação pensada para o século XIX colocam-se como essencial nesse estudo. As configurações têm seus sistemas próprios, mas estão ligadas por interdependências de diversos tipos, formando figurações específicas. Estas, muitas vezes, mudam lentamente, ou seja, elas podem ser formadas por indivíduos de diferentes gerações fazendo com que haja a impressão de que elas existem sem os indivíduos que a compõem. $\mathrm{O}$ fato é que eles podem desaparecer, especialmente quando dão lugar a outros. No entanto, a figuração, bem como a sociedade, é formada por indivíduos. (ELIAS, 2001).

Entendemos, então, ser necessário que os estudos sobre a configuração da profissão docente considerem a lei como fonte. Compreender a sua natureza é fundamental para entender as propostas, os modelos e a legislação do ensino primário no Brasil do século XIX; para analisar o processo de implantação das instituições desse ensino; para entender o caráter formador que tiveram essas instituições e os padrões civilizatórios que tentaram estabelecer, especialmente no que diz respeito a configuração da profissão docente no âmbito do ensino primário.

De fato há evidências que confirmam as funções da lei como mistificadora e expressão de um grupo social. Mas, é preciso considerar também a lei em termos de sua lógica, das suas regras e dos seus próprios procedimentos. A lei como lei, sem a qual não é possível conceber nenhuma sociedade complexa. [...] A lei sempre foi um espaço de conflito e não de consenso. As relações entre os grupos são expressas, não de qualquer modo que se queira, mas através das formas da lei. (NASCIMENTO, 2011, p. 6)

Montesquieu (2008) afirmou que todos os seres possuem suas leis e que elas são as relações necessárias que advêm da natureza das coisas, que os homens não eram guiados 
por suas fantasias, mas que as leis e os costumes cumpriam esse papel de ordenação do comportamento humano. Além disso, para ele, cada lei estaria ligada a outra ou dependeria de outra mais geral.

Para Faria Filho (1998), é possível relacionar as dimensões do fazer pedagógico através da legislação na medida em que a política educacional e as práticas educacionais se perpassam em uma dinâmica que transcende a ideia dela como expressão e imposição dos interesses das classes dominantes. Nesse sentido, o texto normativo está relacionado com as práticas sociais, não surgindo em um vácuo.

Portanto, este artigo visa compreender como se deu o processo de institucionalização da escola primária e da configuração da profissão docente através da análise da legislação do período, na Província de Sergipe.

\section{Notas sobre o início do processo de configuração da profissão docente no Brasil e em Sergipe: a Lei de instrução de 15 de outubro de 1827 e a Lei de 5 de março de 1835}

Como mencionado anteriormente, no que diz respeito às escolas de Primeiras Letras, a primeira lei no século XIX sobre esse assunto foi promulgada por D. Pedro I em 15 de outubro de 1827. Nela foram estipulados os ordenados dos professores entre $200 \$ 000$ (duzentos mil réis) e $500 \$ 000$ (quinhentos mil réis) anuais ${ }^{4}$; o método a ser utilizado, era o mútuo.

O método de ensino mútuo, muitas vezes também chamado de Lancasteriano ou Monitorial, foi desenvolvido separadamente por Andre Bell (1753 - 1832) e Joseph Lancaster (1778 - 1838). O primeiro, médico e pastor anglicano, aplicou os princípios desse método em Madras, na Índia, onde dirigiu um orfanato entre 1787 e 1794 . Não podendo contar com mestres capacitados, utilizou os alunos mais avançados como monitores e que transmitiam aos demais os conhecimentos adquiridos com o professor. $\mathrm{O}$ segundo, religioso Quaker, criou uma escola para crianças pobres em Londres no ano de 1789. Com dificuldades para instruir gratuitamente grande número de alunos sem utilizar muitos professores, decidiu dividir a escola em várias classes colocando em cada uma delas um aluno mais adiantado como responsável sob orientação direta do professor. (BASTOS, 2006, p. 35).

Há indícios da presença do método de ensino monitorial-mútuo em terras brasileiras mesmo antes de sua adoção como método pedagógico oficialmente determinado pelo Decreto das Escolas de Primeiras Letras de 15 de outubro de 1827, primeira lei sobre a instrução pública do Império do Brasil. Segundo Bastos (2006, p. 40), entre 1819 e 1827 existem diversas referências, embora dispersas, sobre sua utilização no Brasil.

No que se refere aos custos de instalação e manutenção e os relacionados aos utensílios necessários às aulas estes seriam assumidos pela Fazenda Pública. Quanto ao método o professor que não conhecesse deveria instruir-se nas escolas das capitais à sua própria custa.

Nas escolas de Primeiras Letras os professores ensinariam, além de ler e escrever, as quatro operações de Aritmética, prática de quebrados, decimais e proporções, noções mais gerais de Geometria Prática, Gramática da Língua Nacional, princípios de moral cristã e da doutrina da religião católica apostólica romana, proporcionais à compreensão dos meninos. Para as leituras seriam utilizadas a Constituição do Império e a História do Brasil.

Também foi permitida a criação de escolas femininas nas cidades e vilas mais populosas, desde que os Presidentes dos Conselhos julgassem-nas necessárias. Para as 
meninas o currículo seria diferenciado, pois não seriam ensinadas noções de Geometria, mas somente seriam instruídas em Aritmética, no que diz respeito às quatro operações e aprenderiam as prendas que serviriam à economia doméstica, além das disciplinas acima mencionadas.

Para essas aulas seriam nomeadas mestras ${ }^{5}$ que, sendo brasileiras e de reconhecida honestidade, mostrassem ter maior conhecimento quando dos exames feitos publicamente perante o Presidente da Província, em Conselho. Após serem nomeadas, elas receberiam os mesmos ordenados e gratificações que eram concedidos aos mestres.

Essa Lei demonstrou a preocupação que as autoridades brasileiras tinham quanto à remodelação do modelo educacional que vigorava até então, tendo como meta incutir novos padrões e culturais que dessem ao povo brasileiro uma nova identidade. Assim, era preciso educar e instruir essa jovem nação e a Lei de Instrução de 15 de outubro de 1827 foi um dos instrumentos utilizados para alcançar tal objetivo.

Essa mesma Lei implantou no Brasil o método lancasteriano ${ }^{6}$. Os ideais de extensão da instrução foram corporificados naquela lei que previu a criação de escolas para meninos e meninas em vilas, povoados e cidades onde fossem necessárias.

Essa lei é contemporânea de um lento, mas paulatino, fortalecimento de uma perspectiva político-cultural para a construção da nação brasileira e do Estado Nacional que via na instrução uma das principais estratégias civilizatórias do povo brasileiro. (FARIA FILHO, 2000, p.137).

Entre os motivos que explicam a proposição do método Lancasteriano ao Brasil, estava o fraco quadro educacional que o referendava como apropriado na medida em que eram minímos os recursos de toda a ordem, fato que o levou à condição de método ideal, uma vez que passava a contar com o auxílio dos alunos mais adiantados, resolvendo, assim, o problema do baixo número de mestres e do alto custo que representavam para os cofres públicos.

A intenção era que somente um professor fosse responsável por centenas de alunos, resolvendo o problema do número reduzido de profissionais capacitados para ensinar, além de fazer com que o custo fosse menos dispendioso.

Através desse método os alunos mais adiantados e orientados pelo professor, teriam a responsabilidade de ensinar os colegas mais atrasados que seriam divididos em pequenos grupos para receber a instrução. No entanto, naquela época, a maioria da população escolarizável era constituída de crianças pardas e de pais incógnitos e eram essas crianças que frequentavam as escolas de Primeiras Letras.

Assim, a partir da década de 1830, surgiram diversas discussões sobre a implantação da escola pública elementar e da escolarização de crianças, negros, índios e mulheres. $\mathrm{O}$ fato é que

o século XIX pode ser caracterizado como o tempo de invenção e legitimação da forma escolar moderna no Brasil, ainda que iniciativas nesta direção possam ser evidenciadas desde o período colonial, seja por meio das iniciativas católicas, seja por intermédio das aulas régias. (GONDRA; SCHUELER, 2008, p. 82).

No que diz respeito à configuração do trabalho docente, pode-se afirmar que antes do surgimento das Escolas Normais não havia um corpo de saberes específicos que 
demonstrasse a habilitação dos professores para ensinar e que fossem além das matérias que seriam ensinadas por eles.

Aqueles que se dispunham a exercer esse ofício precisavam apresentar um atestado de moralidade e demonstrar que possuíam os conhecimentos que deveriam ministrar como: escrever, contar e ter conhecimentos relacionados à religião para proporcionar tal ensinamento aos alunos. Aqueles que tinham a intenção de ensinar poderiam ser professores adjuntos e, dessa forma, acompanhariam um professor experiente com o objetivo de aprender a exercer essa profissão na prática.

Nesse processo, os professores foram chamados a obedecer regulamentos na medida em que o Estado assumia cada vez mais o controle da educação formal através da definição de conteúdos e comportamentos, tanto por parte dos professores quanto dos alunos. Nesse sentido, o Estado teve papel essencial na profissionalização dessa categoria especialmente no seu recrutamento, contratação e formação, mesmo que esses processos fossem realizados de maneira inadequada.

Salienta-se a relevância dessa investigação como contribuição para o estudo de uma época, na qual, no contexto educacional, a educação doméstica refletia a representação de que a Educação realizada na Casa contribuía para a manutenção de um estatuto de diferenciação social e também refletia o temor que os pais possuíam de colocar suas crianças para estudar nas escolas existentes à época por conta de questões relacionadas à saúde, preconceito, disciplina ou rivalidade.

Portanto, para as elites no século XIX, a educação doméstica era amplamente aceita e reconhecida como a maneira mais adequada para que seus filhos e filhas recebessem ensinamentos. No entanto, naquela época havia nacionalmente um intenso debate a respeito de qual seria o limite, a partir da instrução e da educação, em que seria responsabilidade do Estado educar e/ou instruir as crianças, pois não bastaria aos aprendizes a obtenção de conhecimentos de Português, Música, Línguas etc. Era também preciso fazê-los adquirir princípios essenciais à convivência social.

Após a publicação da Lei de 1827, nas Províncias teve início a construção de um conjunto de ordenamentos legais relativos à organização da instrução primária, como Leis, Decretos, Regulamentos etc. No caso da Província de Sergipe a primeira destas leis foi a de 5 de março de 1835.

Estas leis são importantes na medida em que a partir da análise da legislação podese compreender como o processo mais geral afetava a organização da instrução no âmbito do Império das Províncias. (GOUVEIA, 2008). A análise das legislações implementadas darão uma ideia de como se deu o início do processo de profissionalização na Província de Sergipe, a partir da legitimação da prática docente, levando-se em conta o que estava posto, continuidades e descontinuidades.

\section{A legislação educacional na Província de Sergipe: a Lei de 5 de março de 1835}

Na primeira metade do século XIX, apenas uma parcela mínima da população tinha acesso à escola, o analfabetismo, a violência e a criminalidade imperavam na sociedade sergipana. Também havia a questão da motivação dessa parte da população em colocar seus filhos na escola, pois muitas vezes os que a frequentavam eram mal vestidos, sem o devido asseio e mal alimentados. Muitos somente participavam das aulas para que seus 
pais ficassem desobrigados da vigilância sobre seus filhos. Assim, a escola assumia uma função diferente da que havia sido efetivamente pensada para ela.

Nunes (1984) afirmou que, no início do século XIX, o ensino não havia ido além das aulas ${ }^{7}$ de Primeiras Letras e de Gramática, como no período colonial. Apenas haviam sido acrescentadas algumas cadeiras de Primeiras Letras e outras de Língua Latina na Freguesia de N. S. do Socorro da Cotinguiba em 1813, na Vila de Santo Amaro em 1816 e em Itabaiana, Lagarto e Propriá no mesmo período. No entanto, essa implantação não seguia ordenamento algum e por vezes eram criadas cadeiras de Latim onde nem mesmo havia de Primeiras Letras, como aconteceu na povoação de Laranjeiras. O fato é que a instrução não era pensada de forma sequencial.

A década de 1820 significou um período de organização política, social e econômica, pois, após um período de instabilidade, tomou posse o primeiro presidente da província, o Brigadeiro Manuel Fernandes da Silveira. Portanto, apesar de exportar açúcar, algodão, aguardente, farinha de mandioca, arroz etc., grande parte da população livre era de trabalhadores braçais, agregados, meeiros, rendeiros, ou seja, gente pobre e que vivia nas periferias das grandes propriedades e das vilas. As escolas públicas de primeiras letras recebiam indivíduos desse extrato da população sergipana, em sua maioria alunos pardos e de pais incógnitos, e que dificilmente chegavam ao fim do curso. (NUNES, 1984).

A organização administrativa da província implicava na criação de cargos públicos e de pessoas qualificadas para exercê-los. Assim, foi nesse contexto em que ocorreu a primeira tentativa de estabelecer uma cadeira primária em Aracaju em 1830 através da solicitação das povoações de Laranjeiras, Pé do Banco e Aracaju. No entanto, criar uma escola era criar também uma fonte de gastos e despesas. Devendo ser mantidas pelo poder público que ainda se organizava administrativa e financeiramente, naquele momento, os pedidos não foram concedidos por conta da situação financeira da Província, mas em 5 de março de 1835 foi criada uma cadeira do sexo masculino em Aracaju. (CALASANS, 1951, p. 100).

$\mathrm{Na}$ verdade, depois da independência, a escola pública, gratuita e obrigatória passou a representar um elemento de reafirmação do novo governo do Brasil, pois ela se constituía em um ícone que tinha como objetivo primordial organizar e dar coesão à nova sociedade nacional. Consequentemente, o povo descuidado, atrasado e indolente passou a ser objeto de preocupação das elites intelectuais e políticas. Era preciso pensar a ação de educar como um fenômeno mais amplo e completo, que implicasse transformações interiores, incutindo posturas e valores, para poder adaptar a população ao modelo de sociedade pretendido.

Todavia, os princípios de universalidade, gratuidade, estatismo e laicidade defendidos pelos ilustrados no século XVIII, e que perpassaram pelos homens letrados do século XIX, dariam lugar a novas formas de desigualdade social fomentada pela desigualdade da instrução, pois "se a escola elementar, assumida como responsabilidade do Estado, ampliava o seu raio de abrangência e ganhava visibilidade, seu ensino se mantinha apartado do secundário, destinado às elites". (ALVES, 2002, p. 124).

A Constituição Brasileira de 1824 determinou que os nascidos no Brasil, ingênuos ou libertos; filhos de pais brasileiros, bem como os ilegítimos de mãe brasileira, que nascessem em um outro país, mas tendo domicílio fixo no Brasil; todos os que fossem nascidos em Portugal e em seus domínios assim como os moradores do Brasil na época da Independência e que tivessem interesse em ficar no país; e os estrangeiros naturalizados, tivessem direito à instrução primária gratuita.

Muitas crianças "indesejadas", frutos da miscigenação e órfãs de pai ou mãe, estavam à margem da sociedade, pois se envolviam em crimes e viviam na vadiagem. 
Assim, era preciso tirá-las das ruas a fim de organizar suas vidas e prepará-las para exercerem algum tipo de profissão, papel a ser exercido pelo Estado. Estar fora da escola significava andar pelas ruas e aprender os maus hábitos tão combatidos pelos envolvidos com a escolarização. Existia a preocupação em evitar que as crianças estivessem expostas a relações tidas por perniciosas e que impedissem que a escola alcançasse nelas o objetivo esperado. Assim, a escola primária se constituía em um local onde as crianças seriam educadas, instruídas e preservadas das mazelas sociais do período.

Pode-se observar que os negros estavam impedidos de ter acesso à instrução pública, pois aquela era destinada aos cidadãos brasileiros livres ${ }^{8}$. Apesar disso, os filhos de famílias que possuíam boa condição financeira não frequentavam escolas públicas, mas seus pais optavam pela educação doméstica, por professores particulares ou mesmo colégios particulares.

Nesse sentido, Figueirôa (2007) analisou a contribuição de abolicionistas sergipanos para o projeto de civilização da nação, através das práticas de instrução e educação aos ingênuos. Ao fim da pesquisa a referida autora concluiu que a criação de uma escola de ensino primário fundada por um sergipano que adotou o pseudônimo de "Pai Thomaz" estava relacionada com a liberdade de escravos e ingênuos.

Ela ainda revelou que, na prática, o projeto abolicionista desse sergipano chamado Francisco José Alves enfatizava a inserção no mundo das letras e a inculcação de comportamentos adequados à formação dos ingênuos. Pautada nos moldes civilizatórios do final do século XIX, a escola objetivava fornecer conteúdos mínimos de instrução e propiciar às crianças a prática dos valores morais, patrióticos e religiosos. (FIGUEIRÔA, 2007).

Nesse sentido, para organizar o ensino na província, o Presidente Manuel Ribeiro da Silva Lisboa (1835), fazendo uso das suas atribuições de acordo com o Ato Adicional, promulgou a Carta de Lei de 5 de março de 1835. Sua importância se explica pelo fato dela se constituir em uma minuciosa regulamentação do ensino abarcando temas como provimento das cadeiras por concurso à discriminação do salário de $200 \$ 000$ (duzentos mil réis) que o professor receberia, constituindo-se na remuneração mínima a ser recebida, como propunha a Lei de 15 de outubro de 1827.

A referida lei também organizou os concursos, determinando que seriam convocadas "pessoas hábeis" para examinar publicamente os candidatos sobre as matérias que seriam ensinadas pelos professores, inclusive perante o Presidente da Província e, depois de aprovados, os professores não poderiam ocupar outro ofício qualquer. As cadeiras femininas poderiam ser providas interinamente e sem concurso até que uma mestra fosse aprovada. Salienta-se que a formação dos candidatos era pela prática. Além disso essa lei ainda determinava questões como punições e aposentadoria dos professores.

A obrigatoriedade da realização dos concursos foi uma tentativa de em buscar a profissionalização dos professores, pois sua nomeação sem concurso era comum durante boa parte do século XIX, pois "ajudava" os governantes no resgate de "compromissos" relacionados com a política. (FREITAS; NASCIMENTO, 2008, p. 165). No entanto, é preciso levar em consideração que o fato dos professores terem que estudar as matérias para prestar concurso já contribuía para sua formação, pois eram arguidos sobre os assuntos que iriam ministrar.

A partir da análise da Lei é possível observar o processo de profissionalização docente de maneira clara e objetiva quando o texto legal provincial determinou que os professores e mestras das cadeiras de primeiras letras poderiam requerer um prazo de até seis meses para se "instruírem nas matérias necessárias". Somente poderiam se submeter 
ao concurso após o período concedido, sendo que receberiam, nesse ínterim, apenas metade do ordenado.

Dessa forma, os candidatos concorreriam em igualdade de condições supostamente não havendo indicação alguma de favorecimento. A esse título, foi concedido aos professores e mestras que tivessem mais de doze anos na carreira e que não conseguissem ser aprovados, a aposentadoria com direito a receber metade do ordenado percebido na época.

A instituição dos concursos para a seleção desses profissionais trouxe, assim, um condicionamento de uma cultura profissional voltada para a organização da profissão docente. Além disso, a criação de estatutos, decretos e leis normatizaram e modificaram o papel desse profissional, substituindo a autonomia e a informalidade do professor.

O objetivo seria impedi-lo de seguir livremente uma determinada metodologia em uma tentativa de unificar procedimentos, mas que também expressava uma tensão permanente, vivenciada no ambiente educacional. Os procedimentos dos professores começaram a ser vigiados constantemente, tornando-os passíveis de punição. A realização dos concursos foi uma das ações iniciais do poder público com vistas a exercer esse controle.

O artigo $8^{\circ}$ da Lei de 5 de março de 1835 dá a entender que Noções Gerais de Geometria Prática seria a matéria com maior importância. Ela seria o critério de aprovação no concurso, pois quando não houvesse candidato com conhecimento dela seriam "[...] as mesmas cadeiras providas naquelles, que se mostrarem mais dignos pela approvação que merecerem em concurso nas outras materias declaradas no artigo $6^{\circ}$ da lei de 15 de outubro de 1827'. (FRANCO, 1879, p. 138).

Em seu artigo 11, a Lei ainda oficializou a possibilidade de cadeiras femininas serem providas interinamente e sem concurso até que uma mestra fosse aprovada. Além disso, também permitiu que elas e os professores concursados fossem substituídos, em seus impedimentos, "[...] contanto que os mesmos substitutos tenham sido approvados de igual modo, que são os professores e mestras". (FRANCO, 1879, p. 138).

Porém, quando o motivo do impedimento fosse doença ou serviço público gratuito, havia um procedimento a ser seguido: comunicar às Câmaras Municipais a fim de que tivessem os ordenados pagos integralmente a seus substitutos, o valor referente à metade de duzentos mil réis, valor pago aos professores e mestras.

É significativo observar que havia a previsão de que os professores e mestras fossem presos por algum tipo de crime ou suspensos e nesses casos eles teriam direito a receber apenas metade do ordenado enquanto os substitutos a outra metade. Essas previsões de impedimento se configuravam em ferramentas de controle sobre os professores e mestras deixando claras as consequências pecuniárias advindas de impedimentos como os mencionados.

O fato é que o poder público se dispunha a organizar a profissão docente prevendo salários fixos, a possibilidade do benefício da aposentadoria com ordenado integral, a própria valorização da profissão através dos concursos, vitaliciedade, a garantia de parte da remuneração enquanto os interessados estivessem se preparando para o concurso etc. A contrapartida adviria, dentre outras, da lembrança de que teriam a perder com impedimentos não condizentes com a vida em sociedade e com a posição em que se encontravam.

Outra punição seria a suspensão por crime de prevaricação, irregularidade de conduta, abuso, omissão, segundo o previsto no artigo 22, sendo precedida de informações sobre os fatos pelas Câmaras Municipais e ouvidos os professores. Mas o que seria 
considerado na Lei "irregularidade de conduta"? Isso não foi claramente definido, estando os professores a mercê da discricionariedade do poder público.

Tendo em vista tais questões, é possível pensar nos professores primários do século XIX, na Província de Sergipe como um corpo em processo de socialização, estruturação e incorporação de estruturas imanentes de um campo específico, estruturando tanto a percepção do mundo como a ação deles no mundo, constituindo o seu habitus profissional. (BOURDIEU, 1998).

É significativo lembrar que em um processo civilizador (ELIAS, 1990) que leva em conta a crença de que o indivíduo necessita aprender regras de conduta como requisito da condição humana e que o legitima a viver em sociedade. E, sendo ele socialmente civilizado, a civilização acaba se tornando o resultado de um processo ao qual as pessoas são submetidas. Assim, a História pode ser pensada a partir de agentes individuais que se apresentam combinados com outros em configurações específicas e, nesse sentido, as normas também se apresentam como mecanismos de proteção.

Os casos de jubilação foram especificados na lei, prevendo a invalidez com recebimento de metade ordenado, caso tivessem trabalhado efetivamente por doze anos e "sem nota". O mesmo benefício seria concedido aos que trabalhassem nas mesmas condições por mais de vinte anos, sendo concedido o ordenado completo. Vinte e cinco anos de prática docente efetiva e sem nota dariam o direito ao jubilamento, mesmo sem invalidez.

O fato da previsão de não haver algum acontecimento que "manchasse" o histórico do professor e da mestra precisaria trazer algum benefício e, nesse caso, a aposentadoria proporcional ou completa. Isso os incentivaria a criar a "cultura" do profissional que não somente precisaria ser exemplo de reputação ilibada e profissionalismo na sociedade do XIX, mas também que teria direitos assegurados na legislação que também os protegeriam em casos de invalidez física.

Não era necessário criar um habitus apenas para os professores e mestras, mas para todos os envolvidos no processo. Assim, os juízes de paz e as Câmaras Municipais, eram obrigados a informar ao Governo as irregularidades de conduta, desleixos, omissões e prevaricações para que este tomasse as devidas providências disciplinares. (FRANCO, 1879, p. 138-139).

Segundo o artigo 29, os juízes de paz e as Câmaras Municipais também seriam punidos financeiramente pelo não cumprimento de suas obrigações através de multa: elas, em 100\$000 rs (cem mil réis) e eles, em 20\$000 rs (vinte mil réis), sendo esses valores revertidos para obras públicas do respectivo município (FRANCO, 1879b, p. 139).

A figura do substituto tem lugar de destaque na legislação analisada. O artigo 13 determinou que, quando o motivo da substituição fosse moléstia ou serviço público gratuito, os professores titulares deveriam informar a situação às Câmaras Municipais. Nestes casos eles não teriam desconto algum e os substitutos teriam metade dos ordenados pagos pela Tesouraria Provincial. (FRANCO, 1879b, p. 138).

$\mathrm{O}$ artigo 14 determinou que nos casos de suspensão ou prisão por qualquer crime o ordenado do substituto deveria ser pago pelos professores e mestras nos seus impedimentos. Ou seja, que ele receberia metade do ordenado, descontado de quem estivesse substituindo. Isto garantiria que seu trabalho seria recompensado e que o professor ou professora já fosse punido pelo impedimento. (FRANCO, 1879b, p. 138).

Em caso de demissão, morte, jubilação o substituto seria nomeado interinamente e receberia ordenado completo pago pelas Câmaras Municipais, tendo eles “"[...] preferência 
em igualdade de circunstâncias ao provimento de qualquer das cadeiras, das matérias, que tiverem ensinado como substituto". (FRANCO, 1879b, p. 139).

A responsabilidade pela manutenção das aulas de ensino mútuo foi definida pela lei, no artigo 20, como sendo das Câmaras Municipais que informariam os gastos ao governo para que fossem pagos pela Tesouraria Provincial. As despesas incluíam utensílios e a manutenção do local onde a aula seria ministrada. (FRANCO, 1879b, p. 139).

A previsão era de que as aulas fossem em edifício público, convento ou seria alugada sala própria para as aulas que teriam de ser previamente examinadas e aprovadas pelas câmaras. O governo deveria atender aos estudantes carentes de recursos provendo-os com os livros adotados.

Além dos livros, textos, cartilhas, ortografia, compêndios, cartas, o barro, as resmas, os cadernos, acompanhavam, materiais essenciais, que contribuíram com o processo ensino aprendizagem, como os bancos para a organização e acomodação dos alunos, a mesa, o relógios, elementos que procuraram uniformizar, disciplinar, moldar corpos e mentes. (LIMA, 2007, p. 119).

Pouco a pouco o ensino primário na província foi tomando forma legal, instituindose em uma organização básica que nortearia as relações institucionais e delimitaria o perfil do professor do século XIX. Observa-se ainda que a lei de 1835 tinha como foco profissionalizar e legitimar a profissão docente, pois a maior parte dos artigos se referia às mestras e professores.

Numa tentativa de uniformizar o currículo de Primeiras Letras, a Lei de 1835 estabeleceu no artigo 21 que as disciplinas em que os professores seriam avaliados nos concursos seriam as mesmas instituídas na Lei de 15 de outubro de 1827:

[...] ler, escrever, as quatro operações de aritmética, prática de quebrados, decimais e proporções, as noções mais gerais de geometria prática, a gramática de língua nacional, e os princípios de moral cristã e da doutrina da religião católica e apostólica romana, proporcionados à compreensão dos meninos'; preferindo para as leituras a Constituição do Império e a História do Brasil. (TAMBARA; ARRIADA, 2005, p. 24).

Esse tipo de ação convergia para uma tentativa de imposição de hábitos não somente aos alunos, mas também aos professores, sobre os quais também eram depositadas as esperanças da nação quanto ao desenvolvimento do país, pois eram descritas a sequência em que as aulas aconteceriam e o tempo para a execução de cada tarefa. Nesse sentido, as peças normativas foram produzidas para cumprir a função de disciplinar e homogeneizar atitudes e comportamentos no fazer pedagógico.

\section{Considerações finais}

A sociedade via a educação com uma importância cada vez maior, especialmente pela possibilidade de, através dela, conseguir ascensão social. Apesar disso, o ensino primário continuaria entregue a leigos, em sua maioria não possuindo o preparo necessário para desempenhar a função de professor na década de 1830. 
É preciso lembrar que, a partir do momento em que a responsabilidade pelo ensino foi assumida pelo Estado (Reforma Pombalina em Portugal e colônias), instituiu-se o concurso para a seleção dos professores. Para ministrar aulas era necessário obter licença através de concurso, não importando se o objetivo do candidato era o ensino particular ou público, sendo esta uma ação significativa quanto ao processo de institucionalização da profissionalização docente.

Concluindo este trabalho afirmamos que as questões em torno da formação dos professores no Brasil e especificamente em na Província de Sergipe contribuíram para a edificação de discursos a respeito da instrução e da configuração da profissão docente, pois elas fomentaram diversas ações do Estado. Nesse sentido, a escola apareceu como local de transmissão de um saber pedagógico, constituindo-se também como local de circulação desse saber e de grande importância para a instrução elementar no século XIX.

No que diz respeito à formação e desenvolvimento das nações, pode-se afirmar que o papel da escola primária ganhou importância paulatinamente na medida em que houve um processo de socialização e produção da infância em conformidade com o projeto político da sociedade que se pretendia formar naquele período. Nesse processo, houve lutas e resistências, obstáculos que impuseram limites às ações pensadas para alcançar esse objetivo e que, em determinadas circunstâncias, sofreram reapropriações, mutações ou simplesmente aconteceram posteriormente num processo mais lento de aceitação.

Nesse sentido, entendemos que a legislação educacional do período aqui analisado não encerra as discussões sobre o processo de profissionalização docente, mas estabelece parâmetros que configuram juridicamente essa função e a relação administrativa do professor com o Estado.

Além disso, é possível afirmar que o Império pode ser visto como um período de criação de projetos políticos com o objetivo de dar uma identidade à nação brasileira através da formulação de um ideário de progresso com o objetivo de disseminar o conhecimento, instruindo o povo e afastando-o da barbárie. (NASCIMENTO, 1999).

\section{Referências}

ALVES, Cláudia Maria Costa. Cultura e política no século XIX: o exército como campo de constituição de sujeitos políticos no Império. Bragança Paulista: EDUFS, 2002.

BASTOS, Maria Helena Câmara. O ensino monitorial/mútuo no Brasil (1827 - 1854). In: STEPHANOU, Maria; BASTOS, Maria Helena Câmara (Orgs.). Histórias e memórias da

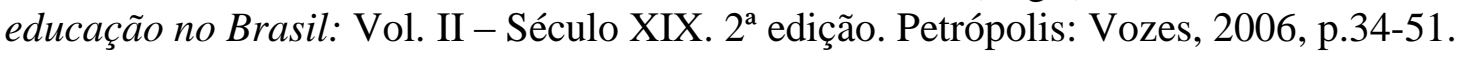

BOURDIEU, Pierre. Razões práticas: sobre a teoria da ação. Tradução de Mariza Corrêa São Paulo: Papirus, 1998.

CALASANS, José. O ensino público em Aracaju (1830-1871). Revista do IHGS, Aracaju, v. 15, n. 2, p. 96-120, 1951.

COSTA E SILVA, Alberto. População e sociedade. In: História do Brasil Nação: (18082010). Crise colonial e Independência. (1808-1830). Rio de Janeiro, Vol. 1. Editora Objetiva, 2011, p. 11.

ELIAS, Norbert. O processo civilizador: uma história dos costumes. Tradução de Ruy Jungmann Rio de Janeiro: Jorge Zahar, 1990. 
ELIAS, Norbert. A sociedade de corte: investigação sobre a sociologia da realeza e da aristocracia de corte. Tradução de Pedro Sussekind. Rio de Janeiro: Jorge Zahar, 2001.

FARIA FILHO, Luciano Mendes. A legislação escolar como fonte para a História da Educação: uma tentativa de interpretação. In: VIDAL, Diana Gonçalves et all. (Orgs.). Educação, modernidade e civilização. Belo Horizonte: Autêntica, 1998. p. 89-125.

FIGUEIRÔA, Meirevandra Soares. "Matéria Livre... Espírito Livre para Pensar": um estudo das praticas abolicionistas em prol da instrução e educação de ingênuos na capital da província sergipana (1881-1884). 2007. 176f. Dissertação (Mestrado em Educação) Universidade Federal de Sergipe, São Cristóvão, 2007.

FRANCO, Cândido Augusto Pereira. Compilação das Leis Provinciais de Sergipe - 1835 a 1880. v. 2: I-Z, Aracaju:Typografia de F. das Chagas Lima, 1879.

FREITAS, Anamaria Gonçalves Bueno de; NASCIMENTO, Jorge Carvalho. As Escolas Normais da Província: a organização do ensino normal em Sergipe durante o século XIX. In: As escolas normais no Brasil: do Império à República. ARAÚJO, José Carlos Souza; FREITAS, Anamaria Gonçalves Bueno de; LOPES, Antônio, de Pádua Carvalho (Orgs.). Campinas: Alínea, 2008. p. 163-175.

GONDRA, José Gonçalves; SCHUELER, Alessandra. Educação, poder e sociedade no Império Brasileiro. São Paulo: Cortez, 2008.

LIMA, Gláriston dos Santos. A Cultura Material Escolar: desvelando a formatação da Instrução das Primeiras Letras na Província de Sergipe (1834-1858). 2007, 147f. Dissertação (Mestrado em Educação) - Universidade Federal de Sergipe, São Cristóvão, 2007.

MOACYR, Primitivo. A instrução e o Império: Subsídios para a História da Educação no Brasil, 1823 - 1853. Vol. 1. São Paulo: Companhia Editora Nacional, 1936.

MONTESQUIEU, Charles Luis de Secondat. O espírito das leis. Tradução de Gabriela de Andrada Dias Barbosa São Paulo: Saraiva, 2008.

NASCIMENTO, Jorge Carvalho do. A cultura ocultada ou a influência alemã na cultura brasileira durante a segunda metade do século XIX. Londrina: Editora UEL, 1999.

NASCIMENTO, Jorge Carvalho do. Problemas de método nos estudos sobre o ensino agrícola e o processo civilizador. In: VIII SIMPÓSIO INTERNACIONAL PROCESSO CIVILIZADOR, HISTÓRIA E EDUCAÇÃO, 2004, Paraíba. Anais... Paraíba: Universidade Federal da Paraíba, 2004. Disponível em: http://www.uel.br/grupoestudo/processoscivilizadores/portugues/sitesanais/anas8/artigos/J orgeCarvalhodoNascimento.pdf. Acesso em: 15 de dez. 2011, p.1-8.

NUNES, Maria Thétis. História da Educação em Sergipe. Rio de Janeiro: Paz e Terra, 1984.

TAMBARA, Elomar; ARRIADA, Eduardo (Orgs). Coletânea de leis sobre o ensino primário e secundário no período imperial brasileiro: Lei de 1827; Reforma Couto Ferraz - 1854; Reforma Leôncio de Carvalho - 1879. Pelotas: Seiva, 2005

VEIGA, Cynthia Greive. História da Educação. São Paulo: Ática, 2007. 


\section{Legislação}

SERGIPE. Lei de 15 de outubro de 1827. In: FRANCO, Cândido Pereira. Compilação das leis Provinciais de Sergipe -1835-1880. Aracaju: Typografia de F. das Chagas Lima, 1879. (v. 1:A-H).

SERGIPE. Lei de 05 de março de 1835. In: FRANCO, Cândido Pereira. Compilação das leis Provinciais de Sergipe -1835-1880. Aracaju: Typografia de F. das Chagas Lima, 1879. (v. 1:A-H). 


\section{Notas}

${ }^{1}$ Doutora em Educação, Professora do Programa de Pós-graduação em Educação da Universidade Tiradentes - PPED-UNIT/SE.

${ }^{2}$ Doutor em Educação, Professor do Programa de Pós-graduação em Educação da Universidade Tiradentes PPED-UNIT/SE.

${ }^{3}$ Mestranda no Programa de Pós-graduação em Educação da Universidade Tiradentes - PPED-UNIT/SE.

4 "Esse detalhe é interessante na medida em que possibilitou aos professores participarem da vida política. De acordo com a constituição, o voto era indireto e masculino, e os cidadãos eram divididos em três categorias: cidadão ativo, com renda mínima de $100 \$ 000$ e que podia votar nos cidadãos eleitores; cidadão ativo eleitor, com renda mínima de $200 \$ 000$ e que escolhia deputados e senadores; e cidadão ativo elegível, com renda mínima de $400 \$ 000$ para deputados e de $800 \$ 000$ para senadores”. (VEIGA, 2007, p. 155).

${ }^{5}$ Durante esse texto as nomenclaturas designadas nas peças legislativas aqui analisadas serão respeitadas e reproduzidas.

${ }^{6}$ Nunes (1984a) afirma que Euzébio Vanério, professor baiano ligado à vida da província sergipana, foi o primeiro professor a utilizar o método lancasteriano ou mútuo. Datando sua utilização a partir de 1817.

7 “[...] as denominações "aula", "aula régia", "escola" e "cadeira" designavam um mesmo modelo: estudos avulsos ministrados por um professor régio - isto é, autorizado e nomeado pelo rei. Somente no século XIX, com a criação dos liceus e de novos colégios, retoma-se a reunião dos estudos, que convive por um bom tempo com a estrutura de aulas avulsas". (VEIGA, 2007, p. 134-135).

${ }^{8}$ Segundo Nunes (1984), a população sergipana na década de vinte do XIX estava calculada em 115.408 (cento e quinze mil, quatrocentos e oito) habitantes, sendo 22.055 (vinte e dois mil e cinquenta e cinco) brancos, 51.067 (cinqüenta e um mil e sessenta e sete) pardos, 40.786 (quarenta mil, setecentos e oitenta e seis) pretos e 1.500 (mil e quinhentos) índios. 27,17\% desse total eram de escravos, ou seja, 33.335 (trinta e três mil, trezentos e trinta e cinco) pessoas (p. 41). Os pobres e mestiços eram o alvo das políticas relativas à educação pública primária, pois era essa a população que precisava ser civilizada.

${ }^{9}$ Para as meninas, o artigo $12^{\circ}$ excluiu a obrigatoriedade das noções de Geometria, limitou a instrução de Aritmética às quatro operações. Incluiu as prendas que serviam à economia doméstica. (TAMBARA; ARRIADA, 2005, p. 25).
Recebido em
junho-13
Aprovado em
dezembro-13 